\title{
Metabolism of Biotin and Analogues of Biotin by Microorganisms
}

\author{
III. Degradation of Oxybiotin and Desthiobiotin by Lactobacillus plantarum
}

\author{
JEROME BIRNBAUM AND HERMAN C. LICHSTEIN \\ Department of Microbiology, College of Medicine, University of Cincinnati, \\ Cincinnati, Ohio
}

Received for publication 18 May 1966

\begin{abstract}
Birnbaum, Jerome (University of Cincinnati, Cincinnati, Ohio), and Herman C. LICHSTEIN. Metabolism of biotin and analogues of biotin by microorganisms. III. Degradation of oxybiotin and desthiobiotin by Lactobacillus plantarum. J. Bacteriol 92:920-924. 1966.-Lactobacillus plantarum growing in excess oxybiotin degraded a portion to products not utilizable by Saccharomyces cerevisiae. The loss of activity for the yeast suggested that no vitamers of oxybiotin accumulated during the degradation. The initiation of degrading activity was controlled by the $p \mathrm{H}$ of the growth medium and appeared during early stationary phase. Only cells grown in excess oxybiotin could degrade this biotin analogue. Nonproliferating cells grown previously in excess oxybiotin were able to convert biotin to vitamers (active for the yeast) as well as to degrade oxybiotin. Those grown in excess biotin also developed the ability to degrade oxybiotin as well as to convert biotin; however, in this case, the enzymes degenerated more rapidly. Cells grown with excessive amounts of either material were able to degrade desthiobiotin to products not available for the yeast. Both biotin conversion and oxybiotin degradation were found to have the same requirements for $\mathbf{M g}$ and $\mathrm{Mn}$ ions. It was concluded that conversion of biotin to vitamers, and the degradation of oxybiotin or desthiobiotin are functions of the same on closely related enzyme systems.
\end{abstract}

We reported that Lactobacillus plantarum converts biotin sequentially to an avidin-combinable and -uncombinable vitamer, the latter being impermeable to the organism (1). Krueger and Peterson (8) have reported that a similar organism, L. pentosus, degrades biotin to products not utilizable by Saccharomyces cerevisiae, which suggests that no vitamers accumulated. They demonstrated, also, that oxybiotin undergoes the same degradative process. It seemed reasonable to assume that $L$. plantarum would convert oxybiotin, as well as biotin, to vitamers. However, in the present study, L. plantarum was found to be similar to $L$. pentosus in that it degraded excess oxybiotin to products not utilizable by the yeast. Furthermore, it was found that nonproliferating cells, grown previously in either excess biotin or oxybiotin, degraded desthiobiotin, an analogue of biotin inactive for growth of lactobacilli.

\section{Materials AND Methods}

Culture methods. L. plantarum (ATCC 8014) was grown in the medium of Wright and Skeggs (12), modified as described previously (2). D-Biotin or DLoxybiotin (O-heterobiotin) were added at $500 \times$ $10^{-4}$ or $1,000 \times 10^{-4} \mu \mathrm{g} / \mathrm{ml}$, respectively. These concentrations represent a level 100 times that required for maximal growth. Incubation was at $30 \mathrm{C}$ under stationary conditions.

Assays. L. plantarum was used for the assay of biotin and of oxybiotin by the method of Wright and Skeggs (12). Standard curves were prepared for each material. $S$. cerevisiae (ATCC 9896) was used for the assay of DL-desthiobiotin as well as for D-biotin and DLoxybiotin as described by Hertz (7). The conversion of biotin to vitamers was recognized as an increasing difference between the results of the two assays. The degradation of oxybiotin was measured as a loss of activity identical, within experimental error, for both the yeast and the lactobacillus. The degradation of desthiobiotin was seen as a loss of activity only for $S$. cerevisiae since the lactobacillus does not respond to this compound.

Nonproliferating cells. L. plantarum was grown for 12,17 , or $24 \mathrm{hr}$ (growth was followed by turbidity measurements) and removed from the growth medium by centrifugation. The cells were washed in $0.2 \% \mathrm{NaCl}$ and suspended at $1 \mathrm{mg} / \mathrm{ml}$ (dry weight) in the following reaction mixture: $0.1 \mathrm{M}$ acetate, $\mathrm{pH} 4.75 ; 0.1 \%$ 
glucose; $10^{-3} \mathrm{M} \mathrm{MgSO}_{4}, \mathrm{MnSO}_{4}$, and $\mathrm{KH}_{2} \mathrm{PO}_{4} ; 200 \times$ $10^{-4} \mu \mathrm{g} / \mathrm{ml}$ of D-biotin, or $400 \times 10^{-4} \mu \mathrm{g} / \mathrm{ml}$ of DLoxybiotin or DL-desthiobiotin. The mixture was incubated at $37 \mathrm{C}$. At intervals, samples were removed, placed in a boiling-water bath for $5 \mathrm{~min}$, and centrifuged; the supernatant fluid was assayed for biotin conversion or oxybiotin and desthiobiotin degradation.

\section{RESULTS}

Oxybiotin, an analogue of biotin in which the sulfur is replaced by an oxygen atom, has been shown to be as effective as biotin in promoting the growth of lactobacilli $(5,8,10)$. Unlike other biotin analogues, oxybiotin functions without being converted to biotin (1). The question arose as to whether growth of $L$. plantarum in excess oxybiotin would induce the biotin-converting enzymes $(2,3)$. If the system was induced by oxybiotin, would it convert only biotin, or would it act also on the oxygen analogue to form vitamers? Experiments were designed to answer these questions.

L. plantarum was grown in excess oxybiotin for various intervals. Samples were removed after measurement of growth turbidity, and analyses of oxybiotin remaining in the medium and in the free and bound cellular forms were made (11). Assays were performed with the yeast and the lactobacillus (Fig. 1). The absence of any significant difference between the assays over the entire incubation period suggested that vitamers of oxybiotin were not produced. Up to $12 \mathrm{hr}$ of growth, it was possible to recover $100 \%$ of the oxybiotin supplied initially. After this time, recovery began to fall. At $52 \mathrm{hr}$, only $50 \%$ of the initial oxybiotin remained. It appeared, therefore, that the organism metabolized the excess oxybiotin to products not utilizable for either the lactobacillus or the yeast, a situation very similar to oxybiotin degradation by $L$. pentosus (8). The loss of activity for the yeast probably represents a great structural change in the oxybiotin molecule, since this strain of $S$. cerevisiae utilizes a variety of biotin vitamers $(6,10)$.

Relationship of oxybiotin degradation and the conversion of biotin to vitamers. Conversion of biotin is controlled by the $p \mathrm{H}$ of the growth medium (2). Since degradation of oxybiotin began after $12 \mathrm{hr}$, at which time the medium was in the acid range, the effect of $p \mathrm{H}$ upon the initiation of oxybiotin degradation was studied.

Each of two flasks containing growth medium was inoculated with cells of $L$. plantarum. The cultures differed only in the initial $p \mathrm{H}$; culture A was adjusted to $p \mathrm{H} 6.8$, and culture $\mathrm{B}$, to $p \mathrm{H}$ 5.5 before inoculation. Beginning at $12 \mathrm{hr}$ and at

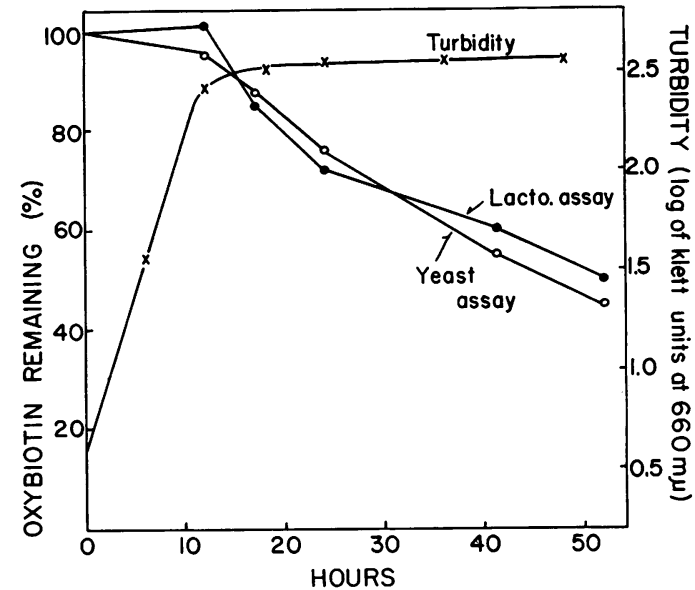

FIG. 1. Degradation of oxybiotin during the growth of Lactobacillus plantarum. Growth measured turbidimetrically with a Klett-Summerson photoelectric colorimeter fitted with a red filter; modified Wright-Skeggs medium; temperature, $30 \mathrm{C}$. Initial concentration of DL-oxybiotin, $1,000 \times 10^{-4} \mu \mathrm{g} / \mathrm{ml}$.

hourly intervals thereafter, measurements were made of $p \mathrm{H}$, turbidity, and oxybiotin remaining (Fig. 2). Degrading activity was detectable first in culture $\mathrm{B}$ at $12 \mathrm{hr}(\mathrm{pH} 4.65)$. No activity appeared in culture $\mathrm{A}$ until $15 \mathrm{hr}$, when the $p \mathrm{H}$ decreased to 4.62. No significant difference in turbidity between the two cultures was observed at any time interval. Thus, the initiation of oxybiotin degradation is similar to the conversion of biotin to vitamers, since both are apparently controlled by the $p \mathrm{H}$ of the growth medium. In fact, the critical $p \mathrm{H}$ for both processes falls within the same range ( $p \mathrm{H} 4.5$ to 4.7$)$ and, therefore, both systems are induced in the same stage of growth (15 hr).

Studies on the effect of initial oxybiotin concentration during growth revealed that oxybiotin degradation occurred in cultures containing $200 \times 10^{-4} \mu \mathrm{g} / \mathrm{ml}$ of the oxygen analogue or higher. Whereas the absolute amount of vitamin degraded increased with increasing levels of oxybiotin in the growth medium, the per cent degraded was highest at $1,000 \times 10^{-4} \mu \mathrm{g} / \mathrm{ml}$ and decreased thereafter. Cells harvested from medium containing $10 \times 10^{-4} \mu \mathrm{g} / \mathrm{ml}$ of oxybiotin (sufficient for maximal growth) were unable to degrade oxybiotin. Intermediate degrading activity was obtained with cells grown at $200 \times 10^{-4}$ $\mu \mathrm{g} / \mathrm{ml}$, and maximal activity was observed with those grown at $1,000 \times 10^{-4} \mu \mathrm{g} / \mathrm{ml}$ or higher. When the inactive $\mathrm{L}$-form of oxybiotin is accounted for, these values are very similar to those for biotin conversion (2). These observa- 


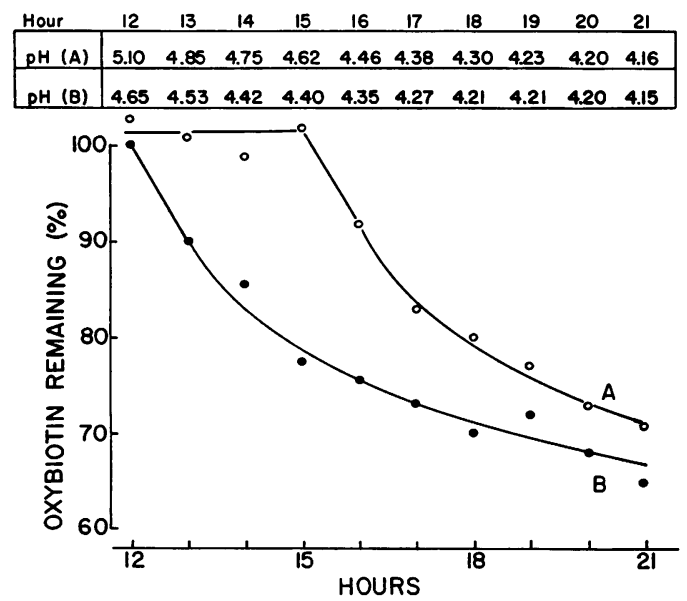

Fig. 2. Effect of pH on time of appearance of oxybiotin degradation in cultures of Lactobacillus plantarum. Initial pH 6.8 (culture A) and 5.5 (culture $B)$; other conditions as for Fig. 1 .

tions suggested that biotin conversion and the degradation of oxybiotin are functions of the same or closely related enzyme systems.

If the two processes are brought about by the same enzymes, growth in either excess biotin or oxybiotin should induce the system. To test this, $L$. plantarum was grown in excess biotin or oxybiotin for 12, 17, and $24 \mathrm{hr}$. The washed cells were placed in the reaction mixture (see Materials and Methods) with biotin or oxybiotin, and incubated at $37 \mathrm{C}$. At intervals, the suspension was boiled and centrifuged, and samples of the supernatant fluid were subjected to differential assay for biotin. Biotin conversion (Fig. 3) in 17-hr cells showed no lag and exhibited similar characteristics for either biotin- or oxybiotingrown cells. There was essentially no activity in 12-hr cells. Converting activity in 24-hr cells was similar, except that those grown with the oxygen analogue showed no lag. This suggested that the converting system did not degenerate as it did when the cells were grown with excess biotin (3). The important point, however, is that cells grown in oxybiotin can form biotin-converting enzymes. Figure 4 shows the oxybiotin-degrading activity of cells grown with either biotin or oxybiotin. Activity in 17-hr cells grown under either condition was similar, whereas 12 -hr cells exhibited no activity. Cells grown with oxybiotin for $24 \mathrm{hr}$ showed degrading activity equivalent to the 17-hr cells, but cells grown for $24 \mathrm{hr}$ in excess biotin exhibited a $60-\mathrm{min}$ lag before oxybiotin degradation ensued. Biotin conversion by these cells followed the same pattern (Fig. 3). Thus, the organism need not be grown in oxybiotin to have degrading activity.

Further evidence for the similarity of the two activities was provided by the $\mathrm{Mg}$ and $\mathrm{Mn}$ requirements (Table 1). It is clear that both functions require $\mathrm{Mg}$ and $\mathrm{Mn}$ ions for maximal activity. When one of the ions was supplied, only partial activity was obtained with either system. The effect of the two ions was not additive, since a doubling of the concentration of either one did not inc "ease activity. Furthermore, the pattern

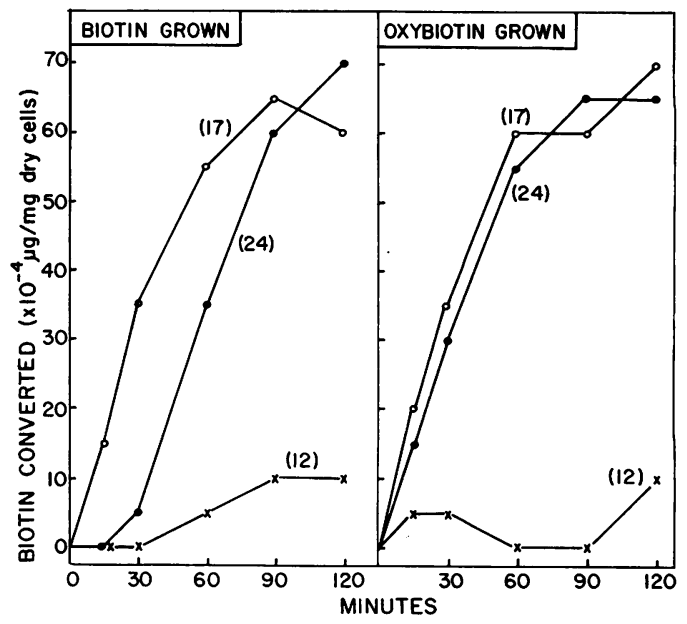

FIG. 3. Conversion of biotin by nonproliferating cell suspensions of Lactobacillus plantarum grown previously in excess biotin or oxybiotin. Contents of reaction mixture as in text; D-biotin for growth, $500 \times 10^{-4}$ $\mu \mathrm{g} / \mathrm{ml}$ DL-oxybiotin for growth, $1,000 \times 10^{-4} \mu \mathrm{g} / \mathrm{ml}$. Numbers in parentheses represent culture age in hr.

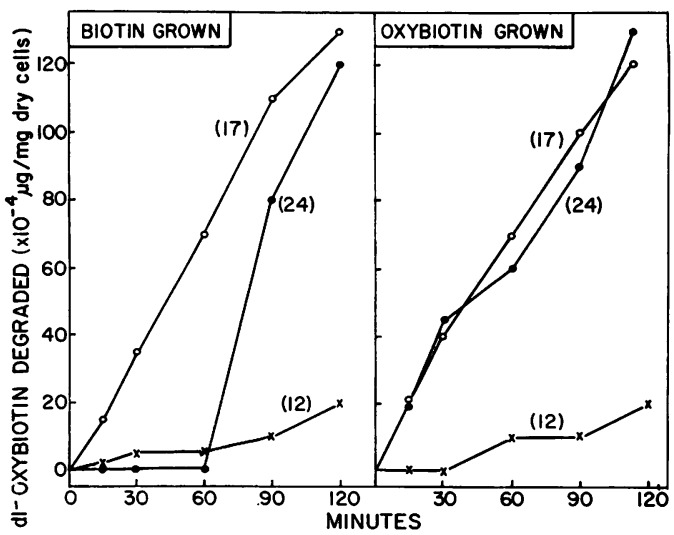

FIG. 4. Degradation of oxybiotin by nonproliferating cell suspension of Lactobacillus plantarum grown previously in excess biotin or oxybiotin. Conditions as for Fig. 3. Number in parentheses represent age of culture in $h r$. 
TABLE 1. Magnesium and manganese requirements for biotin conversion and oxybiotin degradation in Lactobacillus plantarum

\begin{tabular}{|c|c|c|c|c|}
\hline \multirow{2}{*}{$\begin{array}{l}\text { Additions to basal reaction } \\
\text { mixture }^{a}\end{array}$} & \multicolumn{2}{|c|}{ Biotin converted } & \multicolumn{2}{|c|}{$\begin{array}{l}\text { Oxybiotin } \\
\text { degraded }\end{array}$} \\
\hline & $\begin{array}{l}\text { Cells } \\
\text { grown in } \\
\text { biotin }^{b}\end{array}$ & $\begin{array}{c}\text { Cells } \\
\text { grown } \\
\text { in oxy- } \\
\text { biotin }\end{array}$ & $\begin{array}{c}\text { Cells } \\
\text { grown } \\
\text { in } \\
\text { biotin }^{b}\end{array}$ & $\begin{array}{l}\text { Cells } \\
\text { grown } \\
\text { in oxy- } \\
\text { biotin }\end{array}$ \\
\hline None. & $7.2^{d}$ & 6.7 & 7.7 & 0 \\
\hline $10^{-3} \mathrm{M} \mathrm{Mg}^{++} \ldots \ldots$ & 42.9 & 46.6 & 46.1 & 50.0 \\
\hline $10^{-3} \mathrm{M} \mathrm{Mg}^{++}+\mathrm{Mn}^{++}$. & 100 & 100 & 100 & 100 \\
\hline $10^{-3}$ м Mn ${ }^{++} \ldots \ldots \ldots$ & 35.7 & 26.7 & 30.7 & 37.5 \\
\hline $2 \times 10^{-3} \mathrm{M} \mathrm{Mg}^{++}$. & 50.0 & 46.6 & 42.3 & 54.2 \\
\hline $2 \times 10^{-3}$ м Mn ${ }^{++} \ldots$ & 28.6 & 40.1 & 46.1 & 41.7 \\
\hline $\begin{array}{c}2 \times \mathbf{M n}^{-6} \mathbf{M} \mathbf{M g}^{++}+ \\
\mathbf{M n}^{++} \ldots \ldots \ldots \ldots\end{array}$ & 92.8 & 100 & 96.2 & 104 \\
\hline
\end{tabular}

a Basal reaction mixture: $0.1 \mathrm{M}$ acetate, $p \mathrm{H}$ $4.75 ; 0.1 \%$ glucose; $10^{-3} \mathrm{M} \mathrm{KH}_{2} \mathrm{PO}_{4} ; 1 \mathrm{mg}$ of dry cells per ml; $200 \times 10^{-4} \mu \mathrm{g}$ of D-biotin per ml or $400 \times 10^{-4} \mu \mathrm{g}$ of DL-oxybiotin per $\mathrm{ml}$; temperature, $37 \mathrm{C}$; time, $2 \mathrm{hr}$; $\mathrm{Mg}$ and $\mathrm{Mn}$ supplied as sulfate salts.

${ }^{b}$ Cells grown for $17 \mathrm{hr}$ in $500 \times 10^{-4} \mu \mathrm{g}$ of $\mathrm{D}$-biotin per $\mathrm{ml}$.

- Cells grown for $17 \mathrm{hr}$ in $1,000 \times 10^{-4} \mu \mathrm{g}$ of DL-oxybiotin per $\mathrm{ml}$.

${ }^{d}$ Values given as per cent maximal activity.

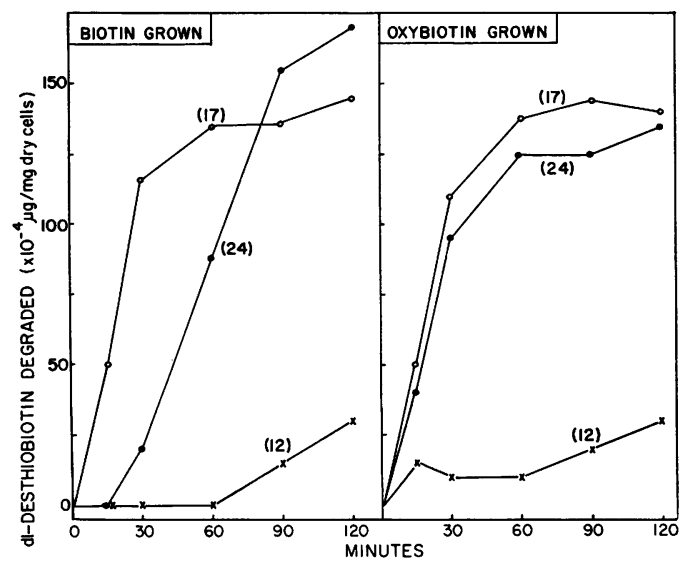

FIG. 5. Degradation of desthiobiotin by nonproliferating cell suspensions of Lactobacillus plantarum grown previously in excess biotin or oxybiotin. Conditions as for Fig. 3. Numbers in parentheses represent culture age in $\mathrm{hr}$.

of the $\mathrm{Mg}$ and $\mathrm{Mn}$ requirement was the same for cells grown in either excess biotin or oxybiotin. When $0.01 \mathrm{M}$ ethylenediaminetetraacetic acid (EDTA) was added to the reaction mixture with
$\mathrm{Mg}$ and $\mathrm{Mn}$, activity for both systems was abolished completely.

The question arose next as to whether cells that convert biotin to vitamers and degrade oxybiotin would also affect desthiobiotin, a naturally occurring analogue of biotin (lacking the sulfur atom) which is not utilizable for growth by lactobacilli $(4,9)$.

For this experiment, cells were grown in excess biotin or oxybiotin and were tested in the nonproliferating state for their ability to degrade desthiobiotin as measured by a loss of yeast assayable activity (Fig. 5). Once again, the cells showed the same patterns of activity for desthiobiotin degradation as for biotin conversion and oxybiotin degradation. Desthiobiotin was not metabolized by $12-\mathrm{hr}$ cells grown in either material. Cells grown in excessive amounts of either compound for $17 \mathrm{hr}$ showed similar activity with no initial lag. Those grown in biotin for $24 \mathrm{hr}$ demonstrated a lag before desthiobiotin degradation ensued. Oxybiotin-grown cells (24-hr) showed the same activity as $17-\mathrm{hr}$ cells, which is similar to the finding with biotin conversion (Fig. 3) and oxybiotin degradation (Fig. 4). Further, cells grown for $17 \mathrm{hr}$ in biotin sufficient for maximal growth did not metabolize desthiobiotin in nonproliferating suspensions.

\section{Discussion}

Several lines of evidence suggest that $L$. plantarum may possess an enzyme system which functions both in the conversion of biotin to vitamers and in the metabolism of oxybiotin and desthiobiotin to products not utilizable by $S$. cerevisiae. The following provides some evidence in this regard: (i) both activities are controlled by $p \mathrm{H}$ and appear at the same hydrogen ion concentration during growth; (ii) both activities appear together, regardless of whether excess biotin or oxybiotin is supplied as inducer; (iii) the same concentration of biotin or oxybiotin in the growth medium induces the same degree of activity for either oxybiotin degradation or conversion of biotin; (iv) both functions have strikingly similar requirements for $\mathbf{M g}$ and $\mathrm{Mn}$ ions; (v) both activities degenerate at $24 \mathrm{hr}$ when the cells are grown in excess biotin; and (vi) both are reinduced simultaneously in 24-hr nonproliferating cells grown in excess biotin. Though such evidence suggests the presence of a single enzyme system responsible for biotin conversion and oxybiotin and desthiobiotin degradation, the possibility remains that two different, but very closely related, systems may exist.

These data coupled with those already presented (3) lead us to suggest that vitamer forma- 
tion may be explained as a flaw in the degradation of biotinlike compounds.

When biotin is present in excess during growth, an intermediate is formed which spills out of the cells and which is impermeable to the cells. This material is only partially degraded, as evidenced by the fact that it retains activity for $S$. cerevisiae. Addition of excess oxybiotin may induce the same enzyme system as postulated above; however, possibly as a result of the slightly different structure of the analogue, no vitamers accumulate, and the degradation can continue until products are formed that are inactive in place of biotin for the yeast. This view is supported further by the finding that desthiobiotin is degraded, also, without the excretion of vitamers into the reaction mixture.

\section{ACKNOWLEDGMENTS}

This investigation was supported by the National Science Foundation (GB-2595) and the Office of Naval Research, Department of the Navy (NR 103555).

We are grateful to Hoffmann-LaRoche Inc., Nutley, N.J., for generous supplies of oxybiotin.

\section{Literature Cited}

1. Axelrod, A. E., B. C. Flinn and K. Hofmann. 1947. The metabolism of oxybiotin in yeast. $\mathbf{J}$. Biol. Chem. 169:195-202.

2. Birnbaum, J., and H. C. Lichstein. 1965. Conversion of D-biotin to biotin vitamers by Lactobacillus arabinosus. J. Bacteriol. 89:1035-1040.
3. Birnbaum, J., AND H. C. Lichstein. 1966. Metabolism of biotin and analogues of biotin by microorganisms. II. Further studies on the conversion of D-biotin to biotin vitamers by Lactobacillus plantarum. J. Bacteriol. 92:913-919.

4. BURK, D., AND R. J. WINZLER. 1943. Heat-labile, avidin-uncombinable, species specific and other vitamers of biotin. Science 97:57-60.

5. Duschinsky, R., L. A. Dolan, D. Flower, AND S. H. Rubin. 1945. "O-heterobiotin," a biologically active oxygen analog of biotin. Arch. Biochem. 6:480-481.

6. EISENBERG, M. A. 1963. Biotin biosynthesis. I. Biotin yields and biotin vitamers in cultures of Phycomyces blakesleeanus. J. Bacteriol. 86:673680.

7. HerTZ, R. 1943. Modification of the yeast-growth assay method for biotin. Proc. Soc. Exptl. Biol. Med. 52:15-17.

8. Krueger, K. K., and W. H. Peterson. 1948. Metabolism of biotin and oxybiotin by Lactobacillus pentosus 124-2. J. Bacteriol. 55:693703.

9. Lilly, V. G., AND L. H. LeONian. 1944. The antibiotin effect of desthiobiotin. Science 99:205206.

10. Sebrell, W. H., aNd R. S. Harris. 1954. The vitamins, vol. 1, p. 557-596. Academic Press, Inc., New York.

11. WALleR, J. R., AND H. C. LiChsteIN. 1965. Biotin transport and accumulation by cells of Lactobacillus plantarum. I. General properties of the system. J. Bacteriol. 90:843-852.

12. Wright, L. D., and H. R. Skeggs. 1944. Determination of biotin with Lactobacillus arabinosus. Proc Soc. Exptl. Biol. Med. 56:95-98. 